\title{
The rhetoric and reality of Lean: A multiple case study
}

Jostein Langstrand and Erik Drotz

\section{Linköping University Post Print}

N.B.: When citing this work, cite the original article.

This is an electronic version of an article published in:

Jostein Langstrand and Erik Drotz, The rhetoric and reality of Lean: A multiple case study, 2015, Total quality management and business excellence (Online).

Total quality management and business excellence (Online) is available online at informaworldTM:

http://dx.doi.org/DOI:10.1080/14783363.2015.1004307

Copyright: Taylor \& Francis (Routledge): SSH Titles

http://www.routledge.com/

Postprint available at: Linköping University Electronic Press

http://urn.kb.se/resolve?urn=urn:nbn:se:liu:diva-113675 


\title{
The Rhetoric and Reality of Lean: A Multiple Case Study
}

\author{
Jostein Langstrand ${ }^{1,2} \&$ Erik Drotz $^{1}$
}

1. Quality Technology and Management, Department of Management and Engineering, The Institute of Technology, Linköping University

2. HELIX VINN Excellence Centre, Linköping University

Corresponding author:

Jostein Langstrand

Department of management and engineering

Linköping University

58183 Linköping Sweden

jostein.langstrand@liu.se

\begin{abstract}
In this paper, we analyze similarities and differences between descriptions of Lean found in the extant literature and how it is applied in practice. Using a multiple case study with seven cases from different sectors, we offer seven propositions about Lean as applied in reality and the relation to descriptions in literature. Our results indicate that organizations adopt the general rhetoric, and repeat the message conveyed by Lean proponents, in terms of rationale for and expected outcomes of applying Lean. Furthermore, we see that the decision to implement Lean often precedes the identification of problems in the organization, which causes a risk of an unfocused change process. The Lean initiatives also tend to have a rather narrow scope, which contradicts the holistic view advocated in the literature. This, together with variation in operationalization, makes it difficult to predict the outcomes of a Lean initiative. Our study suggests that our findings do not depend on organization size, sector or industry.
\end{abstract}

Keywords: Lean; rhetoric; operationalization; multiple case study 


\section{Introduction}

There is a stark contrast between rhetoric and reality of Lean. The influential descriptions of Lean found in popular management literature are hardly recognizable when studying the actual efforts made under the Lean banner. Apart from the label 'Lean' there is little resemblance between the two. On a general level, it seems as if there are two distinctly different versions of Lean. Whereas popular management literature convey a unified canonical version of Lean, what we see in practice is often a different thing altogether. Throughout this paper, we demonstrate this contrast and discuss its implications.

Much research has been devoted to conceptual discussions about Lean, and several authors have tried to define the concept (Dahlgaard and Dahlgaard-Park, 2006, Shah and Ward, 2007, Pettersen, 2009). However, the research community has not found consensus on a precise definition of Lean. Anyone seeking knowledge about Lean will therefore need to assess a large number of information sources, which of course is difficult and time consuming. An extended line of enquiry would thereby involve practice, and not only theory. Thus, it is necessary to determine similarities and differences between the general discourse and the concept as practiced in organizations.

In this paper we challenge the assumption of Lean as a single and well-defined entity and, most importantly, the assumption that implementation of Lean will entail a certain range of predictable outcomes. Instead of bowing to a priori definitions of Lean, we approach the concept with a more open perspective and ask ourselves the following question: What do organizations do when they 'do Lean'?

Many researchers have pointed to the gap that often exists between the rhetoric and reality of change initiatives (Zbaracki, 1998, Gallear and Ghobadian, 2004, Bendell, 2005, Venkateswarlu and Nilakant, 2005, Soltani et al., 2007, Green, 2012). Several studies have shown that there are considerable differences between Lean as practiced in reality compared to many descriptions in literature (Poksinska et al., 2010, Brännmark et al., 2012). Also, the management literature is full of unreasonable claims about the benefits of Lean. To paraphrase Zbaracki (1998), some sources generate increasingly inflated claims about the power and efficacy of Lean, which leads to an increasingly imprecise technical meaning of Lean. Green (2012) summarizes this problem.

The pressure to demonstrate success can lead to inflated claims concerning specific improvements that, in turn, can lead to the unwarranted focus on questionable outcomes. The management rhetoric advertising these successes can thus move substantially away from reality, can serve to broaden the said rhetoric/reality gap and can make success even harder to achieve. (Green, 2012)

As suggested by Pettersen (2009), this lack of precision can have several undesirable consequences. Firstly, this induces a validity problem for studies that seek to determine the effects of Lean. This makes it difficult to know what to look for when researching Lean, and reduces the feasibility of cross-case analyses. Further, practitioners aiming to introduce Lean are faced with unreasonable expectations as a result of inflated claims about expected results and organizational span. Discussing Lean and learning across organizations will also be difficult with such large variation (cf. Brännmark et al., 2012).

In this paper, we use three dimensions of Lean (cf. Zbaracki, 1998). Firstly, the technical dimension includes methods and techniques that are presented under the Lean umbrella. Secondly, the rhetorical dimension represents overall principles, goal formulations and expected outcomes from applying Lean. And finally, the organizational dimension pertains to the organization of work and division of responsibility within organizations that apply Lean. 
The purpose of this paper is to analyze and compare conceptual representations (found in literature) and actual applications of Lean (empirically demonstrated) in terms of technical, rhetorical and organizational aspects of Lean.

We do not aim to make formal generalizations about how Lean is applied or the outcomes that the concept generates. Rather, we aim to provide a more nuanced image of Lean initiatives and challenge some of the general assumptions that exist, in both literature and the popular debate. By doing this, we will illustrate the differences between rhetorical and practical applications of Lean and thereby challenge some of the received knowledge concerning Lean, in terms of espoused values, goals, tools, drivers and organizational outcomes.

The structure of the paper is based on a comparison between the extant Lean literature and our empirical findings. We therefore begin with a summary of the main ideas in the Lean literature, and then move on to a description of our study. In the discussion section of the paper, we present seven propositions about the differences between the literature and our empirical findings. The paper concludes with a general discussion of our contribution and implications for theory development and practical application of Lean.

\section{An overview of the Lean literature}

Lean production was made famous by Womack et al. (1991), and was immediately presented as a universally applicable concept. Womack et al. suggest that "Lean production will supplant both mass production and the remaining outposts of craft production in all areas of industrial endeavor to become the standard global production system of the twenty-first century" (p. 278). Despite the strong association with manufacturing, Lean has reached immense popularity over the years, and is currently dominating the management discourse in several different industries. In addition to manufacturing, Lean has been applied in a wide range of organizations, such as local government (Furterer and Elshennawy, 2005), nonprofit organizations (Cheng and Chang, 2012), service (Suárez-Barraza et al., 2012, Di Pietro et al., 2013) and healthcare (Dahlgaard et al., 2011, Poksinska et al., 2013).

\section{Rationale for Lean}

As with management concepts in general, Lean is associated with a specific terminology and discourse. The Lean rhetoric suggests that Lean is necessary in order to compete in an ever more globalized market (cf. Womack and Jones, 2003). According to its proponents, Lean will make an organization more efficient, improve quality, increase customer satisfaction and generate larger profits, regardless of sector or industry (e.g. Womack and Jones, 2003, Liker, 2004). However, the problems that need solving are quite generic and sometimes unclear (Giroux, 2006, Benders and Slomp, 2009). The rationale for adopting a Lean approach is usually based on vague claims of inefficiency and increased competition (Røvik, 2007). Many authors emphasize Toyota's excellence accompanied by an assumption that their level of performance is attainable by any organization (Womack et al., 1991, Liker, 2004).

Moreover, the purpose of Lean is not clear in the extant literature. Rather, the literature seems to be divided in two categories, with internal or external focus (Pettersen, 2009). Thus, it is not clear whether a Lean approach will focus on cost reduction through waste elimination or generation of customer value.

\section{Philosophies and principles}


Much of the extant literature emphasizes the system aspect of Lean; the entire system must be implemented in order to realize the benefits of Lean (Bicheno, 2004, Liker, 2004). In that sense, Lean is often presented as a philosophy rather than a set of improvement tools (Womack and Jones, 2003, Liker, 2004, Bhasin and Burcher, 2006), and many authors suggest that the universality of Lean lies in the principles rather than in the tools and methods (Hines et al., 2004).

Ohno (1988) describes the goal as the absolute elimination of waste (muda), in terms of overproduction, waiting, transportation, overprocessing, processing, inventory, movement and defects. However, elimination of waste is insufficient if other sources of variation mura (unevenness) and muri (overburdening people or equipment) - are not considered (Liker, 2004).

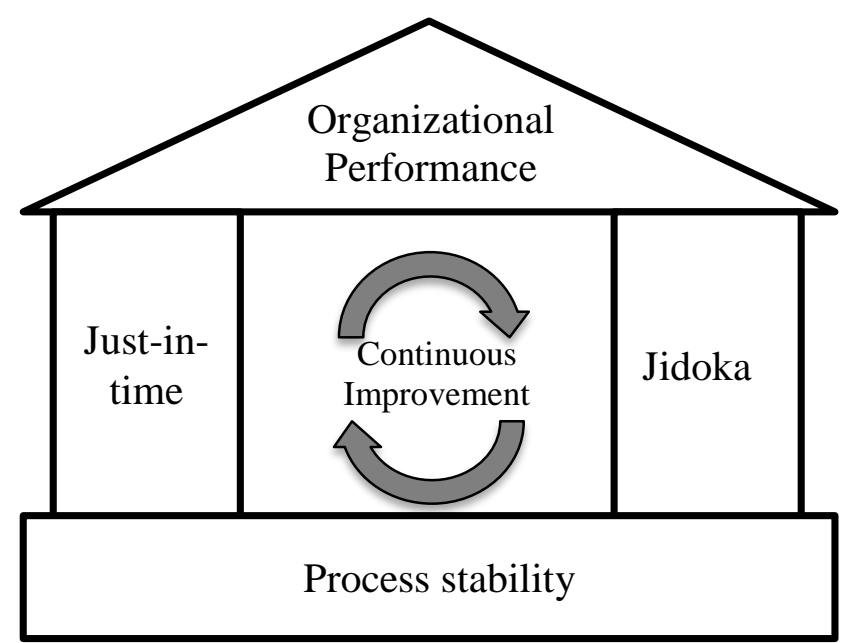

Figure 1 Lean principles visualized as a 'Lean temple'

Liker (2004) argues that Lean is not only a production system, but also a set of management principles. These are often visualized as a temple (Figure 1). The two pillars Just-in-time (JIT) and Jidoka rest on a foundation of stable, standardized and reliable processes. A system of continuous improvement built on waste reduction and empowered employees and teams, will lead to organizational performance.

\section{Organization of Lean work}

Lean also has a dimension concerning the organization of Lean work in terms of responsibility, coordination and the type of processes where it is used. Many authors suggest that a change agent should be assigned (Womack and Jones, 2003). Liker and Meier (2006) emphasize that the initiative should come from top management but generally be driven by middle management. In that sense, change is driven top-down but the aim is to build up an improvement organization that involves all employees. Employees are therefore often seen as the most important resource for productivity improvement (Antoni, 1996), and several authors describe unused creativity as an additional form of waste (e.g. Liker, 2004).

Through empowerment of teams and employees, the need for specialist functions will decrease in the organization (Karlsson and Åhlström, 1996). Instead, the responsibility for planning and control should be delegated to teams. The transfer of management tasks to teams reduces the need for middle managers and the number of organizational layers (delayering). This is further catalyzed by policy deployment (hoshin kanri) and visual management, whereby the basis for decision is communicated and can be seen by all employees, instead of being the sole responsibility of managers. 


\section{Tools and Techniques}

There are many tools and techniques that can be associated with Lean. According to Bicheno (2004) these should be selected based on the organization's need and how they work together as a system. Therefore, not every tool should be used in every organization working with Lean. Tools and techniques can be both operational, supporting the development of the production system, or managerial, supporting the development of the organization (Pavnaskar et al., 2003). Some common tools are value stream mapping, setup-time reduction, 5S/housekeeping, pull production, standardization, improvement boards and production leveling (Pettersen, 2009, Jasti and Kodali, 2014).

\section{Expected results}

Much of the Lean literature presents quite exaggerated claims about the expected outcomes of Lean. For instance, Womack et al. (1991) claim that Lean will result in half the space, half the cost, half the time, and half the human effort. This argument has been criticized by several authors; Williams et al. (1992) argues that the claims lack empirical support and Berggren (1993) argues that there is a discourse that Japanese practice is synonymous with best practice, which should be challenged. More recently, Liker (2004) claims that Lean generates radical improvements in terms of quality, cost, lead time, safety and employee morale. Once again, critics argue that such claims are problematic, since Lean will have different implications from case to case (Benders and Slomp, 2009, Brännmark et al., 2012, Langstrand, 2012).

Rather than making inflated claims about the expected outcomes of Lean, Karlsson and Åhlström (1996) suggest a number of factors that should change in a certain direction as a result of Lean. They suggest i.a. that there should be a decrease in lot size, work in progress, set-up time, machine down time, transportation of parts, scrap and rework, and furthermore that delegation, autonomy and the number of improvement suggestions should increase.

There has also been criticism against Lean, primarily from a work environment perspective. Studies have shown that Lean can lead to increased stress and reduced work content, although these effects could be reduced through increased job autonomy, skill use and participative decision making (Parker, 2003). Landsbergis et al. (1999) have shown that Lean rarely empowers the employees. Instead, the intensified work pace and increased demands can lead to higher job strain and even musculoskeletal disorders.

\section{Method and sample}

The empirical basis of this paper is a multiple case study consisting of seven cases from private and public organizations. The cases have been chosen to represent a wide range of areas where Lean is applied, in terms of industry (manufacturing and service) as well as ownership (private and public). 
Table I Overview of the individual case studies

\begin{tabular}{|c|c|c|c|c|}
\hline $\begin{array}{l}\text { Case } \\
\text { (pseudonym) }\end{array}$ & $\begin{array}{l}\text { Organization } \\
\text { type }\end{array}$ & Ownership & $\begin{array}{l}\text { Approx. no of } \\
\text { employees }\end{array}$ & $\begin{array}{l}\text { Respondent roles } \\
\text { (number of respondents) }\end{array}$ \\
\hline Alpha & $\begin{array}{l}\text { Primary care } \\
\text { unit }\end{array}$ & Public & 25 & $\begin{array}{l}\text { Manager } \\
\text { Doctor (2) } \\
\text { Nurse (3) }\end{array}$ \\
\hline Beta & $\begin{array}{l}\text { Pharmaceutical } \\
\text { company }\end{array}$ & Private & 80 & $\begin{array}{l}\text { Factory manager } \\
\text { Production manager } \\
\text { First line manager (3) } \\
\text { Operator (6) }\end{array}$ \\
\hline Gamma & $\begin{array}{l}\text { Manufacturing } \\
\text { company }\end{array}$ & Private & 2000 & $\begin{array}{l}\text { Managing director } \\
\text { Division manager } \\
\text { Production manager (2) } \\
\text { Floor manager (2) } \\
\text { Supervisor (4) } \\
\text { Lean coordinator (2) } \\
\text { Operator (17) }\end{array}$ \\
\hline Delta & Municipality & Public & 20 & $\begin{array}{l}\text { Facilitator } \\
\text { Quality manager } \\
\text { First line manager (2) } \\
\text { Front line employees (4) }\end{array}$ \\
\hline Epsilon & $\begin{array}{l}\text { Primary care } \\
\text { unit }\end{array}$ & Public & 35 & $\begin{array}{l}\text { Manager } \\
\text { Doctor (4) } \\
\text { Nurse (2) } \\
\text { Secretary }\end{array}$ \\
\hline Zeta & Hospital unit & Public & 20 & $\begin{array}{l}\text { Manager } \\
\text { Doctor (2) } \\
\text { Nurse } \\
\text { Secretary (2) } \\
\text { Analyst (4) } \\
\end{array}$ \\
\hline Eta & $\begin{array}{l}\text { Social } \\
\text { insurance } \\
\text { office }\end{array}$ & Public & & $\begin{array}{l}\text { Group manager (2) } \\
\text { Social worker (4) }\end{array}$ \\
\hline
\end{tabular}

The case studies are mainly based on interviews, along with document studies and direct observations of both meetings and operational work. Two of the cases have been studied longitudinally (Beta: 2009-2011; Gamma: 2007-2011). The remaining cases are cross sectional studies. The aim has been to produce a broad representation of how Lean is applied in the organizations. Thus, respondents have been selected from all categories of employees, from top managers to front-line employees. We have used semi-structured interviews in order to allow the respondents to give their own accounts of transpired events (Kvale, 1997). The interviews have typically ranged from 45 to 90 minutes and have been transcribed verbatim. The outcomes from each case study have been reported back to the organizations in order to validate our findings.

The underlying analytical framework is based on the notion of Lean as a multi-dimensional construct (see discussion above), which emphasizes the need to specify its content in the studied organizations. According to Brännmark et al. (2012), there are several contextual factors that also need to be considered when studying Lean. 
If we are to understand what these organizations actually do as part of their Lean programs, we need to describe the Lean interventions in much more detail. Simply relying on the label Lean tells us little about the contents of the interventions.

(Brännmark et al., 2012)

Building on this observation, the three main dimensions (organizational, technical, rhetorical) of the study along with have been operationalized through the categories listed below. Background (time) and outcomes (change) have been included as additional categories.

\section{Background}

1. Time: When did the Lean initiative start?

\section{Organizational dimension}

2. Actors: Who initiated the work, and who are the main actors now?

3. Focus: In what parts of the organization are Lean techniques/principles applied? Rhetorical dimension

4. Drivers: What was the fundamental problem that Lean was going to solve?

5. Goals: Which goals are associated with the Lean initiative?

6. Inspiration: What/who inspired the organization to introduce Lean?

7. Principles: Which principles guide the Lean initiative?

\section{Technical dimension}

8. Techniques: Which techniques are applied?

9. Measurement: Which performance indicators are connected to the Lean initiative? Outcomes

10. Change: What has changed in the organization (structure, procedures, communication etc.)?

These categories have been converted to codes, which have been applied to the empirical material (notes, transcripts, documents). Following Miles and Huberman (1994), the analysis has been conducted iteratively with coding done individually by each of the authors, followed by a discussion of findings and refinement of the coding system. Through this process, the data has been 'funneled' until both authors have agreed that a point of saturation has been reached (Silverman, 2006).

\section{Summary of cases}

As mentioned above, the empirical basis of this article is seven case studies from various organizations in Sweden. These cases represent a sample of the large variation that exists with reference to Lean and its application. Four of the seven cases have relatively long experience working with Lean - approximately 10 years. In one case (Epsilon), Lean was introduced around 2008. The remaining two organizations (Zeta, Eta) have begun their journey just a couple of years ago. Despite this difference, we see many similarities between the cases - and some differences. These aspects are summarized in Table II below. 


\begin{tabular}{|c|c|c|c|c|c|c|c|c|}
\hline & & Alpha & Beta & Gamma & Delta & Epsilon & Zeta & Eta \\
\hline 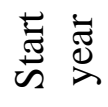 & & 2001 & 2002 & 2003 & 2004 & 2008 & 2010 & 2011 \\
\hline \multicolumn{9}{|c|}{ Organizational dimension } \\
\hline \multirow{2}{*}{ 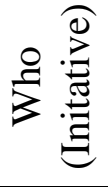 } & Manager(s) & $\bullet$ & $\bullet$ & $\bullet$ & $\bullet$ & $\bullet$ & $\bullet$ & \\
\hline & $\begin{array}{c}\text { Improvement } \\
\text { expert }\end{array}$ & & & & & & & $\bullet$ \\
\hline \multirow{2}{*}{ 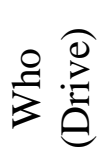 } & $\begin{array}{l}\text { Improvement } \\
\text { group }(\mathrm{s})\end{array}$ & $\bullet$ & $\bullet$ & & & & & \\
\hline & Manager(s) & & & $\bullet$ & $\bullet$ & $\bullet$ & $\bullet$ & $\bullet$ \\
\hline \multirow{2}{*}{ 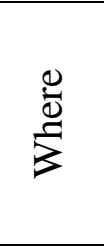 } & $\begin{array}{c}\text { Main processes } \\
\text { (operative) }\end{array}$ & $\bullet$ & $\bullet$ & $\bullet$ & $\bullet$ & $\bullet$ & $\bullet$ & $\bullet$ \\
\hline & $\begin{array}{c}\text { Support } \\
\text { processes } \\
\text { (Administration) }\end{array}$ & & & & $\bullet$ & & & \\
\hline \multicolumn{9}{|c|}{ Rhetorical dimension } \\
\hline \multirow{4}{*}{$\frac{\substack{0 \\
0}}{0}$} & Efficiency & $\bullet$ & & & $\bullet$ & & & \\
\hline & Competitiveness & & $\bullet$ & & & $\bullet$ & & \\
\hline & Stress & $\bullet$ & & & - & & & \\
\hline & Structure & $\bullet$ & - & & $\bullet$ & & & \\
\hline \multirow{6}{*}{$\begin{array}{l}\frac{\infty}{\pi ే} \\
0 \\
0\end{array}$} & $\begin{array}{c}\text { Work } \\
\text { environment } \\
\text { (stress reduction) }\end{array}$ & $\bullet$ & & & & $\bullet$ & & \\
\hline & Better structure & $\bullet$ & $\bullet$ & & $\bullet$ & & & \\
\hline & Higher efficiency & $\bullet$ & $\bullet$ & $\bullet$ & $\bullet$ & & $\bullet$ & $\bullet$ \\
\hline & $\begin{array}{c}\text { Better financial } \\
\text { performance }\end{array}$ & & & $\bullet$ & & $\bullet$ & & \\
\hline & $\begin{array}{c}\text { Customer } \\
\text { satisfaction }\end{array}$ & & & & & $\bullet$ & & $\bullet$ \\
\hline & Availability & & & & & & $\bullet$ & \\
\hline \multirow{4}{*}{ 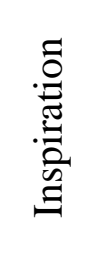 } & $\begin{array}{c}\text { Other } \\
\text { organizations }\end{array}$ & & $\bullet$ & $\bullet$ & & $\bullet$ & & \\
\hline & Courses/seminars & $\bullet$ & & $\bullet$ & $\bullet$ & & & \\
\hline & Consultants & $\bullet$ & & $\bullet$ & $\bullet$ & & & \\
\hline & Past experience & & & $\bullet$ & $\bullet$ & & & \\
\hline \multirow{6}{*}{$\begin{array}{l}\frac{0}{0} \\
\frac{0}{0} \\
\vdots \\
01\end{array}$} & Improvement & $\bullet$ & & & $\bullet$ & & $\bullet$ & \\
\hline & Customer focus & $\bullet$ & & & $\bullet$ & & & $\bullet$ \\
\hline & Delayering & $\bullet$ & $\bullet$ & $\bullet$ & $\bullet$ & & & \\
\hline & Standardization & & - & $\bullet$ & & & & $\bullet$ \\
\hline & Visualization & & & $\bullet$ & $\bullet$ & & & \\
\hline & Other & & & & & $\bullet$ & & $\bullet$ \\
\hline
\end{tabular}




\begin{tabular}{|c|c|c|c|c|c|c|c|c|}
\hline \multicolumn{9}{|c|}{ Technical dimension } \\
\hline \multirow{8}{*}{ 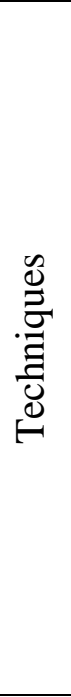 } & $\begin{array}{l}\text { Value stream } \\
\text { mapping }\end{array}$ & & & $\bullet$ & $\bullet$ & & & $\bullet$ \\
\hline & $\begin{array}{c}5 \mathrm{~S}, \\
\text { Housekeeping }\end{array}$ & & & $\bullet$ & $\bullet$ & $\bullet$ & $\bullet$ & $\bullet$ \\
\hline & Flow chart & $\bullet$ & & & & & $\bullet$ & • \\
\hline & $\begin{array}{l}\text { Improvement } \\
\text { boards }\end{array}$ & $\bullet$ & $\bullet$ & $\bullet$ & $\bullet$ & $\bullet$ & $\bullet$ & $\bullet$ \\
\hline & Layout changes & & & $\bullet$ & & & & \\
\hline & $\begin{array}{c}\text { Production } \\
\text { leveling }\end{array}$ & & & & & $\bullet$ & & $\bullet$ \\
\hline & $\begin{array}{l}\text { Improvement } \\
\text { cycle (Plan-Do- } \\
\text { Study-Act) }\end{array}$ & & & & & & $\bullet$ & $\bullet$ \\
\hline & Pulse meetings & & $\bullet$ & $\bullet$ & & $\bullet$ & & $\bullet$ \\
\hline \multirow{4}{*}{$\frac{\mathscr{e}}{e^{0}}$} & $\begin{array}{c}\text { Overall } \\
\text { equipment } \\
\text { efficiency }(\mathrm{OEE})\end{array}$ & & $\bullet$ & & & & & \\
\hline & $\begin{array}{c}\text { General metrics } \\
\text { (Safety, Quality, } \\
\text { Efficiency, } \\
\text { Financial results) }\end{array}$ & & $\bullet$ & & & & & \\
\hline & Availability & & & & & $\bullet$ & & \\
\hline & Other & & & & & & & $\bullet$ \\
\hline \multicolumn{9}{|c|}{ Outcomes } \\
\hline \multirow{10}{*}{ 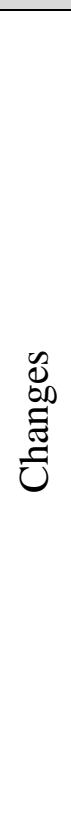 } & $\begin{array}{c}\text { Work } \\
\text { environment }\end{array}$ & $\bullet$ & & & & & & \\
\hline & $\begin{array}{c}\text { Layout } \\
\text { adjustments }\end{array}$ & & & $\bullet$ & & $\bullet$ & & \\
\hline & Availability & $\bullet$ & & & & & & \\
\hline & $\begin{array}{c}\text { Increased } \\
\text { cooperation }\end{array}$ & & $\bullet$ & & & $\bullet$ & $\bullet$ & \\
\hline & $\begin{array}{l}\text { Work/process } \\
\text { standardization }\end{array}$ & $\bullet$ & $\bullet$ & & • & & & \\
\hline & Efficiency & & & $\bullet$ & $\bullet$ & $\bullet$ & & \\
\hline & Financial results & & & $\bullet$ & $\bullet$ & & & \\
\hline & $\begin{array}{l}\text { New perspectives } \\
\text { and terminology }\end{array}$ & $\bullet$ & $\bullet$ & $\bullet$ & $\bullet$ & $\bullet$ & $\bullet$ & $\bullet$ \\
\hline & $\begin{array}{c}\text { Customer } \\
\text { satisfaction }\end{array}$ & & & & $\bullet$ & & & \\
\hline & Other & & & & & & $\bullet$ & $\bullet$ \\
\hline
\end{tabular}




\section{Organizational dimension of the changes}

A general result in the studied organizations is that the initiative to introduce Lean came from someone in a managerial position. A slight deviation can be found in the Eta case, where the initiative came from an internal improvement expert (swe: verksamhetsutvecklare). However, in terms of driving the Lean effort, we can see some differences. For the majority of the cases, the managers have taken charge, but in two of the cases (Alpha and Beta), the responsibility is delegated to improvement teams. Thereby, the main role of management was seen as encouraging employees to make improvement suggestions.

Requesting improvements is the biggest part of what managers do.

(First line manager at Beta)

The efforts are predominantly focused on the operative parts (main processes) of the organization. This is likely no surprise for the majority of the readers. Lean principles and techniques have been developed in a production environment, and are usually discussed with reference to manufacturing and other processes that follow a similar logic. Although the possibility of applying Lean in administrative environments has received some attention in recent years, it has not yet reached substantial popularity.

\section{Rhetorical dimension of the changes}

It is interesting to note that most of the studied cases are surprisingly vague in terms of underlying problems and reasons for introducing Lean. In three of the cases, no problem description can be found, and the interviewees often describe the aim of Lean, rather than the problem behind it.

Well... the goal is to reduce wasted time and things like that.

(Employee at Eta)

Well, we want to improve the flow in our work, and to have all employees feel needed, and increase the awareness about problems and what we do well (Employee at Gamma)

In two cases, competitiveness is presented as a driver, and increased efficiency is the main objective for most cases. Only Epsilon does not have this as an explicit goal. This is in line with the vague problem description discussed above, and also a reflection of the general rhetoric found in literature. In the majority of the cases, we can conclude that it is unclear which problem Lean is supposed to solve. Only two of the studied cases (alpha and delta) have a clear problem or question to which the Lean initiative is an answer.

We had too much to do, were stressed, and did not have time [...] to do what we are trained for $[\ldots]$. And that was the starting point for us $[\ldots]$ before we initiated our improvements. Then we found a way to improve our work environment [...], and that is when we started to consider Lean. (Manager at Alpha)

The examples above are quite representative for how Lean is described at the overall level. It is interesting to note the similarity between the expected effects described by the respondents and the popular management literature, respectively. However, when it comes to more operational descriptions of Lean, we see - not surprisingly - that our respondents tend to relate them to the specific techniques that are applied, and management and front line employees tend to have different interpretations (cf. Langstrand, 2012).

When it comes to inspiration, it is quite clear that courses, seminars, consultants and other organizations are among the main sources. In some cases, we see that past experience plays a 
role. It is interesting to note that none of the cases indicate that universities have played any role in this sense. This is in line with a previous study by Poksinska et al. (2010).

There is considerable variation in terms of guiding principles for the change. However, two principles stand out; improvement and delayering. Seeing as improvement is a main characteristic of all management concepts, it may seem surprising that it is not represented in all cases. This is a result that can have different implications. A plausible explanation is that most people see improvement as an implicit part of Lean, and do not feel the need to mention it explicitly. Another possibility is that the purpose of Lean has been unclear in the organizations in question, and that improvement has not been a driver for implementation. In the Eta case, the Lean initiative has been defined through a number of different keywords that summarize both goals and guiding principles: Customer value, visual control, safety, environment, structure, leadership, leveling, continuous improvement, efficiency, quality and standardization. In other words, Lean seems to be considered a universal solution for almost all existing and potential problems in this organization. Epsilon, on the other hand, does not have any particular principles that guide the improvement work. Rather, improvements have been made ad-hoc, through directives from management. This is a contrast against most of the other cases, where a more participative/cooperative approach has been applied.

\section{Technical dimension and outcomes of the changes}

In terms of techniques, we see that all of the cases, without exception, have some sort of improvement board. Improvement boards are commonly used for 'pulse meetings' or visual management. However, this use is only observable in three of our seven cases. General visualization is only mentioned in one of the cases (Delta).

We work a lot with visualization, how [we] can see that the goal is reached, who is responsible and so on. (Quality manager at Delta)

When it comes to actual changes or improvements that have been achieved as a result of the Lean initiatives in these organizations, we have two very interesting findings. First of all, we can see that organizations with clearly formulated problems and goals have also managed to improve in the desired direction(s). Probably the best example is Beta, which has a welldefined strategy for the Lean work with both short and long term goals. Clear goals for each year are visualized in a strategy map displayed on the improvement boards. Furthermore, a general result in all of the cases is that their efforts have provided new perspectives and new terminology, and the way of thinking about the daily activities has changed. Employees indicate that their thinking is more oriented towards e.g. value, flow and waste.

I think I have become more (...) into looking at the value and (...) the value flows and really focus on what is not good and see opportunities. (Employee at Zeta)

Other important results are increased cooperation (both vertically and horizontally); more standardized work processes; and increased efficiency. These results can be observed in three of the seven cases - however, not in the same cases. In the Zeta and Eta cases, the establishment or further development of an infrastructure for change (improvement teams and structure for improvement) is seen as an outcome of the organizations' respective Lean initiatives.

We have had the philosophy [to improve] during a long time, but now we have a tool to realize the thoughts. (Employee at Zeta) 


\section{Discussion}

As we see from table II, it is difficult to describe Lean as a homogenous concept. For most characteristics, we see considerable variation between cases, and also several divergences from the extant literature. Based on the observations in the table, we would like to highlight some points and put forward seven propositions.

The first point we would like to stress is that the use of 'traditional' Lean terminology is quite extensive in most cases, despite different sectors and sizes of organization. In contrast to what is recommended in previous studies (Røvik, 2007, Benders and Slomp, 2009, Langstrand, 2012), the terminology does not seem to be translated or adapted to organizations based on different contextual factors.

\section{P1: The Lean rhetoric does not change with organization, sector, industry, size or other contextual factors}

As indicated above, the descriptions of Lean are very similar across the cases, regardless of various contextual factors. This is both positive and negative. The positive is that it promotes learning between the different organizations. We can see this in several cases where individuals have been recruited across sectorial borders from organizations with long traditions of working with Lean. In such cases, it is easier to use their experience into the new organization if the terminology is the same.

The negative is that some terms lack contextual fit. For instance, many employees within the public sector do not identify themselves with terminology that is used in the manufacturing industry. This is supported by this study as well as in previous research. A common expression is "we work with people, not cars".

A derivation of our first proposition is that the rationale for introducing Lean is similar across cases. Context specific requirements are thus often overlooked, and little attention is given to the actual problem(s) that should be solved. This leads to our second proposition.

\section{P2: Underlying problems are usually generic, and the expected benefit of implementing Lean is often unclear}

Our study suggests that Lean initiatives are rarely preceded by specific problems that a Lean program may solve. Instead, the initiatives are justified by using more general terms such as competitiveness, efficiency and customer satisfaction (in line with the general rhetoric). We argue that the need for increased competitiveness is another way of expressing a felt need to improve, without having anything concrete to point to. This argument finds support in previous research (Westphal et al., 1997, Giroux, 2006, Benders and Slomp, 2009). In other words, the actual driver in these cases is likely to be institutional pressure or management fashion (cf. Meyer and Rowan, 1977).

According to Venkateswarlu and Nilakant (2005), this kind of underlying problem, or 'pull factor', is an important factor for the success or failure of change. In some cases, we see indications that the drivers for change are vague or constructed, which could be seen as artificial pull factors. This resonates with many publications on the subject, and is probably an effect of the 'pragmatic ambiguity' innate in the Lean concept (Giroux, 2006, Benders and Slomp, 2009). Metaphorically speaking, we can argue that Lean is the cure, but the disease is often unknown or unclear. 
As indicated by proposition 2, we rarely see clearly defined problems that necessitate a Lean initiative. This often causes Lean initiatives to be driven by the implementation of a solution rather than solving a problem, which leads to our next proposition.

\section{P3: Lean initiatives are often oriented towards solutions rather than problems}

As suggested above, the medicine is often prescribed before the diagnosis is made. Thus, introducing Lean is not always driven by a strictly rational logic. Given the general nature of problems described in the general Lean rhetoric, it is easy to argue that improvements are necessary. But for an individual organization, one needs to identify which specific problems they face (Benders and Slomp, 2009). As seen in table I, this is not always the case. Although we only have anecdotal evidence, it seems that management fashion and institutional forces are important drivers for introducing Lean (cf. Benders and Bijsterveld, 2000, Røvik, 2007, Brännmark et al., 2012).

A more sympathetic interpretation is that the actual goal is more about general improvement rather than solving specific problems in the organization. In line with the metaphor above, Lean is not necessarily seen as a medicine, but as an exercise program for improving health and preventing disease. Accordingly, most of our cases have general goals and metrics for the Lean initiatives, as illustrated in table I.

Despite the great similarities in terminology rhetoric suggested above, the same pattern is not found in terms of operationalization of Lean in the studied organizations.

\section{P4: Lean initiatives often have a narrow scope}

Many established authors advocate a structured and planned approach of Lean implementation (cf. Womack and Jones, 2003, Liker, 2004). However, in our cases, implementation is often left to the employees to decide in a continuously ongoing process, rather than designed in detailed plans. Another argument in literature is also that the 'entire system' should be implemented (e.g. Liker, 2004, Di Pietro et al., 2013). But our cases show no such holistic approach, and very few principles and techniques are applied. This is in line with a previous study by Radnor et al. (2012), and also supported by an extensive literature review by Jasti and Kodali (2014). Our respondents tend to describe Lean as a set of principles, rather than techniques and tools. Based on the framework by Pettersen (2009), the interpretations are biased towards 'Lean thinking' with little emphasis on the remaining dimensions of Lean (doing, being, becoming). Many scholars raise a warning finger against a strict practice oriented interpretation of Lean ('toolbox Lean'), and we believe that a similar warning is warranted in this case. A more balanced approach - with emphasis on philosophy as well as techniques, processes and goals - is probably preferable. This balanced approach is found in the Alpha and Delta cases.

Our next proposition can be seen as a result of the lack of alignment between rhetoric, goals and practice that is indicated by our first four propositions.

\section{P5: Interpretations of Lean vary between and within organizations, and with hierarchical position}

This proposition may seem to contradict our first proposition (P1), as the rhetoric is very similar across cases. However, when it comes to operational descriptions, variation increases. Several studies have indicated variation in how Lean is interpreted, especially between organizations (see above). Our study reinforces this finding, and also suggests that a similar interpretative variation exists within organizations, depending on the work role and 
hierarchical position. In our study, the respondents' descriptions of Lean on a practical level are strongly connected to the techniques that are applied in their own daily work.

One consequence of this is that a limited sample of respondents leads to a risk of bias. For instance, studies based on interviews with managers often suggest that Lean is largely a management issue, while our study indicates that frontline employees strongly influence the actual practice. This finding may also have explanatory power for our next proposition.

\section{P6: It is difficult to identify and predict outcomes of a Lean initiative}

The problem of prediction has been stressed in previous research (Pettersen, 2009, Brännmark et al., 2012), and is a direct effect of the operational variation discussed above. While our material does not allow formal generalizations, we see a strong contrast between the espoused results in the Lean literature (both positive and negative) and the results that are observable in our study.

In our cases, we can see many different outcomes of the respective Lean initiatives, but it seems that new terminology is a recurring theme. Another common outcome is the reduction of hierarchical structures. In many of the cases, introducing Lean seems to have facilitated delegation of managerial tasks to employees. Furthermore, the communication patterns have changed in many cases, from one-way to two-way communication, and problem solving has improved. This resonates with the study by Suárez-Barraza et al. (2012), which suggests that Lean often implies a strong focus on organizational capabilities.

However, the quantitative effects are not as clear. There are examples of measurable outcomes (see e.g. Gamma, Delta and Epsilon), but we are not able to explain these results based on the techniques that are applied in the respective organizations. However, what we can say is that the organizations that lack alignment between general rhetoric, problem definition, goals and actions (see discussion above) have not demonstrated measureable results. Extending this line of inquiry, we argue that it is unreasonable that unfocused change initiatives will have any significant effects, which leads to our final proposition.

\section{P7: The likelihood of success increases with a stronger alignment of change characteristics}

In several cases, we can see a divergence between the core characteristics of change. Problems are not defined, goals are vaguely expressed and no metrics or analyses are connected to the chosen course of action. However, in two of our cases (Alpha and Delta) the Lean initiatives are based on clearly defined problems to which clear goals and actions are connected. In other words, these two cases go against the general trend. Not surprisingly, we see that the organizations manage to solve their problems and improve the organizational aspects they have addressed. Based on this observation, we suggest that stronger alignment between key characteristics of the change process (problem definition, goals, metrics, analysis, practices) will increase the likelihood of reaching the desired results. If these change characteristics diverge - as they do in the remaining cases - or if some characteristics are not addressed, the change initiative is likely to become unfocused and ineffective.

\section{Conclusion}

In this paper, we put forward seven propositions for how to understand changes towards Lean. In line with the findings by Alsmadi et al. (2012), our study suggests that there is no significant difference between manufacturing and service in terms of these propositions. We suggest that the general rhetoric does not change across cases, and there is rarely a specific 
problem that underpins the Lean initiative. A consequence of this is that the solution is often defined before the problem. Furthermore, the change initiatives often have a narrow scope, and the application of techniques and principles is very limited. The changes usually focus on creating structures for improvement and building organizational capabilities $(5 \mathrm{~S}$, improvement teams, delayering, improvement boards, flow charts) rather than applying techniques for specific improvements (e.g. JIT, Heijunka, Poka-yoke).

Based on our analyses, we argue for a problem based implementation, meaning that an organization should first identify and define the problems that require attention, and then choose approaches and methods that target these problems (cf. Bicheno, 2004), thereby seeking alignment between the various elements of the change process (cf. proposition 7). Our study suggests that such an approach has a better probability of success as opposed to choosing methods first and then looking for problems to solve. An implication of this suggestion is that the organization must be prepared to diverge from the general descriptions found in literature, and be critical to the received knowledge.

In our study, we see that what is done under the Lean banner differs from case to case. This tendency will be further reinforced if organizations apply our recommendations above. For this reason, we believe that the ambition to predict the results from a general concept such as Lean is unreasonable. We therefore argue that this variation needs to be acknowledged by academics; rhetoric and practice should be treated as separate phenomena, and research on Lean implementation needs to go beyond the 'label' and consider the operationalized practice associated with the general concept. Future research should thereby lower the level of abstraction and aim to establish the effects of specific techniques rather than the overall concept.

It is important to emphasize that the observations made in this study are not iron clad conclusions. Our empirical foundation is rather limited, which is why we have chosen to present our results in the form of propositions. Furthermore, our entire study is embedded in a Swedish context, which could influence the results. We encourage similar studies in other countries to test the potential impact of national cultures. We also encourage research that builds on our results and test the external validity of our propositions. Following Gallear and Ghobadian (2004), we argue that the potential contribution of Lean may be lost if its theoretical and rhetorical foundation is not critically assessed and defined.

\section{References}

Alsmadi, M., Almani, A. \& Jerisat, R., 2012. A comparative analysis of Lean practices and performance in the UK manufacturing and service sector firms. Total Quality Management \& Business Excellence, 23, 381-396.

Antoni, C., 1996. Lean production in Europe: a matter of technical adjustment or cultural change? Applied Psychology, 45, 139-142.

Bendell, T., 2005. Structuring business process improvement methodologies. Total Quality Management and Business Excellence, 16, 969-978.

Benders, J. \& Bijsterveld, M.V., 2000. Leaning on lean: The reception of a management fashion in Germany. New Technology, Work and Employment, 15, 50-64.

Benders, J. \& Slomp, J., 2009. Struggling with solutions; a case study of using organisation concepts. International Journal of Production Research, 47, 5237-5243.

Berggren, C., 1993. Lean Production -The End of History? Work, Employment \& Society, 7, 163-188. 
Bhasin, S. \& Burcher, P., 2006. Lean viewed as a philosophy. Journal of Manufacturing Technology Management, 17, 56-72.

Bicheno, J., 2004. The new lean toolbox: towards fast, flexible flow: Picsie Books Buckingham.

Brännmark, M., Langstrand, J., Johansson, S., Halvarsson, A., Abrahamsson, L. \& Winkel, J., 2012. Researching Lean: Methodological implications of loose definitions. Quality Innovation Prosperity, 16, 35-48.

Cheng, C.-Y. \& Chang, P.-Y., 2012. Implementation of the Lean Six Sigma framework in non-profit organisations: A case study. Total Quality Management \& Business Excellence, 23, 431-447.

Dahlgaard, J.J. \& Dahlgaard-Park, S.M., 2006. Lean production, six sigma quality, TQM and company culture. The TQM Magazine, 18, 263-281.

Dahlgaard, J.J., Pettersen, J. \& Dahlgaard-Park, S.M., 2011. Quality and lean health care: A system for assessing and improving the health of healthcare organisations. Total Quality Management \& Business Excellence, 22, 673-689.

Di Pietro, L., Mugion, R.G. \& Renzi, M.F., 2013. An integrated approach between Lean and customer feedback tools: An empirical study in the public sector. Total Quality Management \& Business Excellence, 24, 899-917.

Furterer, S. \& Elshennawy, A.K., 2005. Implementation of TQM and lean Six Sigma tools in local government: a framework and a case study. Total Quality Management \& Business Excellence, 16, 1179-1191.

Gallear, D. \& Ghobadian, A., 2004. An empirical investigation of the channels that facilitate a total quality culture. Total Quality Management and Business Excellence, 15, 1043-1067.

Giroux, H., 2006. 'It Was Such a Handy Term': Management Fashions and Pragmatic Ambiguity. Journal of Management Studies, 43, 1227-1260.

Green, T.J., 2012. TQM and organisational culture: how do they link? Total Quality Management \& Business Excellence, 23, 141-157.

Hines, P., Holweg, M. \& Rich, N., 2004. Learning to evolve: A review of contemporary lean thinking. International Journal of Operations \& Production Management, 24, 994-1011.

Jasti, N.V.K. \& Kodali, R., 2014. Lean production: literature review and trends. International Journal of Production Research, 1-19.

Karlsson, C. \& Åhlström, P., 1996. Assessing changes towards lean production. International Journal of Operations \& Production Management, 16, 24-41.

Kvale, S., 1997. Den kvalitativa forskningsintervjun Lund: Studentlitteratur.

Landsbergis, P.A., Cahill, J. \& Schnall, P., 1999. The impact of lean production and related new systems of work organization on worker health. Journal of Occupational Health Psychology, 4, 108-130.

Langstrand, J., 2012. Exploring organizational translation : a case study of changes toward Lean Production Linköping: Department of Management and Engineering, Linköping University.

Liker, J.K., 2004. The Toyota Way New York: McGraw-Hill.

Liker, J.K. \& Meier, D., 2006. The Toyota Way Fieldbook: A Practical Guide for Implementing Toyota's 4Ps; [companion to the International Bestseller" The Toyota Way"]: McGraw-Hill.

Meyer, J.W. \& Rowan, B., 1977. Institutionalized Organizations - Formal-Structure as Myth and Ceremony. American Journal of Sociology, 83, 340-363.

Miles, M.B. \& Huberman, A.M., 1994. Qualitative data analysis: An expanded sourcebook: Sage Publications, Incorporated.

Ohno, T., 1988. Toyota production system: beyond large-scale production: Productivity press. 
Parker, S.K., 2003. Longitudinal effects of lean production on employee outcomes and the mediating role of work characteristics. Journal of Applied Psychology, 88, 620-634.

Pettersen, J., 2009. Defining lean production: some conceptual and practical issues. The TQM Journal, 21, 127-142.

Poksinska, B., Pettersen, J., Elg, M., Eklund, J. \& Witell, L., 2010. Quality improvement activities in Swedish industry: drivers, approaches, and outcomes. International Journal of Quality and Service Sciences, 2, 206-216.

Poksinska, B., Swartling, D. \& Drotz, E., 2013. The daily work of Lean leaders - lessons from manufacturing and healthcare. Total Quality Management \& Business Excellence, 24, 886898.

Radnor, Z.J., Holweg, M. \& Waring, J., 2012. Lean in healthcare: the unfilled promise? Social Science \& Medicine, 74, 364-71.

Røvik, K.A., 2007. Trender og Translasjoner: Ideer som former det 21. århundrets organisasjon Oslo: Universitetsforlaget.

Shah, R. \& Ward, P.T., 2007. Defining and developing measures of lean production. Journal of Operations Management, 25, 785-805.

Silverman, D., 2006. Interpreting qualitative data : methods for analyzing talk, text and interaction, 3 ed. London: SAGE.

Soltani, E., Lai, P.-C. \& Mahmoudi, V., 2007. Managing change initiatives: Fantasy or Reality? The case of public sector organisations. Total Quality Management and Business Excellence, 18, 153-179.

Suárez-Barraza, M.F., Smith, T. \& Dahlgaard-Park, S.M., 2012. Lean Service: A literature analysis and classification. Total Quality Management \& Business Excellence, 23, 359-380.

Venkateswarlu, P. \& Nilakant, V., 2005. Adoption and persistence of TQM programmes-case studies of five New Zealand organizations. Total Quality Management \& Business Excellence, 16, 807-825.

Westphal, J.D., Gulati, R. \& Shortell, S.M., 1997. Customization or Conformity - An institutional and network perspective on the content and consequences of TQM adoption. Administrative Science Quarterly, 42, 366-394.

Williams, K., Haslam, C., Williams, J. \& Cutler, T., 1992. Against lean production. Economy and Society, 21, 321-354.

Womack, J.P. \& Jones, D.T., 2003. Lean thinking : banish waste and create wealth in your corporation, Rev. and updated [ed.] ed. London: Free Press Business.

Womack, J.P., Jones, D.T. \& Roos, D., 1991. The machine that changed the world : [the story of lean production] New York: HarperPerennial.

Zbaracki, M.J., 1998. The rhetoric and reality of total quality management. Administrative Science Quarterly, 43, 602-636. 